\title{
Factors affecting mortality of neonatal sepsis in Moewardi Hospital, Surakarta
}

\author{
Yulidar Hafidh, Dwi Hidayah, Sunyataningkamto
}

\begin{abstract}
Background Mortality of neonatal sepsis is still a significant problem. It might be affected by many factors.

Objective The purpose of this study was to determine factors which affect mortality of neonatal sepsis at neonatal ward of Moewardi Hospital, Surakarta.

Methods Data of neonatal sepsis was obtained from medical records at the neonatal ward of Moewardi Hospital from December 2004 to November 2005. We recorded data from 97 neonatal sepsis consisted of 46 male and 52 female babies. Statistical analysis had been performed using univariate Chi-square and multivariate multiple logistic regression analysis.

Results Overall neonatal sepsis mortality was about 40\%. There were no significant difference in factors associated with mortality of neonatal sepsis such as gender $(\mathrm{OR}=0.44 ; 95 \% \mathrm{CI} 0.19 ; 1.014)$, referral patients $(\mathrm{OR}=1.61 ; 95 \% \mathrm{CI} 0.195 ; .014)$, and bacterial growth culture $(\mathrm{OR}=1.96$; $95 \% \mathrm{CI} 0.856 ; 4.44)$, except for birth weight which affected mortality $(\mathrm{OR}=6.29 ; 95 \% \mathrm{CI} 2.57 ; 15.42)$. Conclusion Birth weight affects mortality of neonatal sepsis in Moewardi Hospital. Patients with positive bacterial growth culture has two times higher risk of death, however, it is not statistically significant. [Paediatr Indones 2007;47:74-77].
\end{abstract}

Keywords: neonatal sepsis, low birth weight, bacterial infection

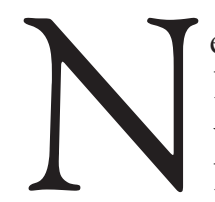
eonatal sepsis is still a significant prob lem found both in developing and de veloped countries. Even though there has been advance in therapy, the morbidity and the mortality are still high. The total of sepsis cases in developing countries is $1.8-18 / 1000$ of birth while in developed country is 4-5/1000 of birth. ${ }^{1}$ The total of sepsis cases in Cipto Mangunkusumo Hospital during the period of January-September 2005 was $13.68 \%$ of the whole lived birth with $14.8 \%$ of mortality rate. ${ }^{2}$ Despite advances in neonatal care, overall case fatality rate of sepsis ranges from 2 to $50 \% .^{3}$ The high number of cases and mortality rate can be reduced by controlling the risk factors. There are many factors that may affect mortality in neonatal sepsis such as low birth weight, prematurity, and bacterial infection. ${ }^{4-6}$

Previous studies in neonatology unit, Moewardi Hospital found that neonatal sepsis due to Coagulase Negative Staphylococcal had death risk five times higher than that caused by Gram-negative pathogens. It were statistically insignificant. ${ }^{7}$ The purpose of the study was to investigate the risk factors that affect the neonatal sepsis mortality in neonatology unit, Moewardi Hospital.

\section{Methods}

This was an analytical descriptive study. Data was obtained from neonatal sepsis medical records of high

From the Department of Child Health, Medical School, University of Sebelas Maret, Moewardi Hospital, Surakarta, Indonesia.

Reprint request to: Yulidar Hafidh, MD, Department of Child Health, Medical School, University of Sebelas Maret, Moewardi Hospital, Surakarta, Indonesia. 
Yulidar Hafidh et al: Factors affecting mortality of neonatal sepsis

major and minor, which is also being used in neonatology unit, Cipto Mangunkusumo Hospital. ${ }^{12}$ Special approach is expected to achieve earlier patient identification and more efficient management. The classical sepsis signs and symptoms that may occur in children, are never found in neonates. Blood culture which serves as gold standard in diagnosis takes three to five days to give result. Laboratory test, e.g. C-reactive protein and I/T ratio are not specific and difficult to be used as a marker in the diagnosis of sepsis. This situation causes delay in antibiotic administration resulting in the death of the patients. ${ }^{13}$

In this study, the mortality of neonatal sepsis is high. We are not yet able to identify the specific causes. The definition of death as a result of sepsis used in this study, may overestimate the effect of sepsis as the primary cause of death. Without extensive postmortem examination of all patients, cause of death in neonates is often difficult to establish.

Birth weight plays an important role in neonatal sepsis. Jarvis ${ }^{4}$ reported that $9 \%$ of neonatal sepsis occurred in babies with birth weight of equal or more than $2500 \mathrm{~g}$, and $46 \%$ of those occurred in babies with birth weight of $1000 \mathrm{~g}$. It has also been reported that birth weight and gestation age is highly related to late sepsis, and rate of infection is inversely related to birth weight. ${ }^{5}$ This study showed significant difference in neonatal sepsis between babies with birth weight of $\geq 2500 \mathrm{~g}$ and babies with birth weight of $<2500 \mathrm{~g}$. Twenty-eight babies with low birth weight (62\%) died and the other 17 (38\%) survived. This study also indicated that low birth weight is the most significant factor in the mortality of neonatal sepsis.

This study indicated that gender was insignificant in neonatal sepsis prevalence $(\mathrm{P}=0.10)$ and did not affect the mortality $(\mathrm{OR}=0.62 ; 95 \% \mathrm{CI} ; 0.29-1.54)$. This finding corresponds with the study done by Stoll et al. ${ }^{5}$

Moewardi Hospital is a referral hospital located in the center of Surakarta. In this study, more than half of the subjects were referral patients (57\%). However, we could not present the indication of admission. Research implemented by Paul et $a^{14}$ in India showed that sepsis is the most common indication for neonatal admission to the district and subdistrict hospitals. Prevalence of low birth weight (LBW) and preterm babies in developing countries is high, caused by unhygienic conditions. Thus, a large proportion of acquired infections (umbilical infection, skin infec- tion, clinically-suspected sepsis, and lack of access to medical care) seems to be the main reasons for such a high proportion of deaths due to infections. ${ }^{15-17}$ These conditions are different in developed country; patients are referred for management of surgical, cardiac, and genetic conditions; also for management of extreme prematurity with $12 \%$ of overall mortality as a result of sepsis. ${ }^{6}$ In this study, the number of death in the referral group was high, reaching 45\% (25 subjects). Beside the causes mentioned above, there are also other causes such as lack of awareness of the community on health disturbance of the newborn which results in late referral, lack of equipment supporting physiological function, inappropriate transportation, and lack of health personnel for referral.

Blood culture is considered as the gold standard. This research showed that from 97 clinically septic subjects, 47 infants (48.5\%) were diagnosed as sepsis with positive bacterial growth culture. Eventhough blood culture is considered as gold standard, the reliability of blood culture for small blood samples has not been well-evaluated, and it is not free of error, considering that mother may have received antibiotics during labour, suppression of bacterial growth by previous antibiotic administration to baby, or false-positive contamination during collection. ${ }^{13,18}$

Previous study in neonatology unit, Moewardi Hospital, indicated that the most common bacteria causing sepsis in neonatology unit, Moewardi Hospital were enterobacter (42.9\%). It was followed by Staphylococcus and Citrobacter (18.4\%), Streptococcus and Serratia (6.1\%), Pseudomonas and Klebsiella (4.1\%). Neonatal sepsis caused by CoNS had death risk 5 times higher than that caused by Gram-negative pathogens. ${ }^{?}$ Tseng et $a l^{6}$ found that mortality due to nosocomial bloodstream infection was the highest one among Gram-negative bacteria, especially with $P$. aeruginosa. This study showed that neonates with positive bacterial growth culture have two times higher risk of death.

In conclusion, birth weight might contribute to the death of patients with neonatal sepsis at Moewardi Hospital. Patients with positive bacterial growth blood culture have two times higher risk of death. Due to limited independent variable measurement, further investigations are needed to find out the influence of other factors on the mortality of neonatal sepsis. 
risk infants at Moewardi Hospital, who had underwent blood culture and antibiotic sensitivity examinations during the period of 12 months from December 2004 to November 2005. The diagnosis of neonatal sepsis was based on the presence of clinical signs such as lethargy, apneu, takipneu, tachycardia, bad perfusion, hypotension, cyanosis, unstable temperature, hypoglycemia, or drinking difficulty. ${ }^{8}$ Factors that may affect neonatal sepsis mortality included birth place, gender, birth weight, and blood culture result. Statistical analysis was done using univariate Chisquare and multivariate multiple logistic regressions reversed to 95\% confidence interval index with SPSS 10.0 for Windows.

\section{Results}

During the period of one year, from December 2004 to November 2005, there were 97 neonatal sepsis cases who underwent blood culture and sensitivity tests, consisted of male (54\%) and female infants $(46 \%)$. More than half of the infants were born outside Moewardi Hospital (57\%). Forty-five infants (46\%) had birth weight of less than $2500 \mathrm{~g}$, and 52 infants (54\%) with birth weight of more than 2500 g. There were seven infants (7\%) with very low birth weight. The lowest weight was $800 \mathrm{~g}$ and the highest was $4700 \mathrm{~g}$. There were 47 infants (48.5\%) who had indication to undergo bacterial growth culture examination. Table 1 shows that there are no significant differences for gender, place of delivery, and blood culture result; yet, it shows significant difference for birth weight.

Table 1. Characteristics of subject

\begin{tabular}{lccc}
\hline Variable & \multicolumn{2}{c}{ Number } & P \\
& $\mathrm{n}$ & $\%$ & \\
\hline Gender & & & \\
$\quad$ Male & 52 & 54 & 0.10 \\
$\quad$ Female & 45 & 46 & \\
Birth weight & & & \\
$\quad \leq 2500$ gram & 45 & 46 & 0.00 \\
$\quad>2500$ gram & 52 & 54 & \\
Place of delivery & & & \\
$\quad$ Transported & 55 & 57 & 0.23 \\
$\quad$ Moewardi Hospital & 42 & 43 & \\
Blood culture & & & \\
$\quad$ Positive growth & 47 & 48.5 & 0.09 \\
$\quad$ Negative growth & 50 & 51.5 & \\
\hline
\end{tabular}

The mortality rate of neonatal sepsis in this study was $40 \%$ (39 infants). Factors that may affect the fatality of neonatal sepsis are figured in Tables 2 and 3. Univariate analysis revealed that birth weight $\leq 2500 \mathrm{~g}$ affected the mortality of neonatal sepsis with $\mathrm{OR}=6.14$ (95\% CI 2.50;15.07). Infants with positive bacterial growth culture had higher death risk though it was not statistically significant (95\% CI 0.89;4.65). Place of delivery, gender, and blood culture results did not affect mortality of neonatal sepsis. Multivariate analysis showed that birth weight $\leq 2500$ g strongly influenced the mortality with $\mathrm{OR}=5.21 \quad(95 \% \mathrm{CI}$ 2.04;13.32).

\section{Discussion}

In England mortality of neonatal sepsis has decreased from $25-30 \%$ in $1985-1987$ to $10 \%$ in $1996-1997,{ }^{9}$ even the research in Yale-New Haven Hospital showed that sepsis-related mortality has steadily decreased over the past 75 years, from $87 \%$ in 1928 to $3 \%$ in $2003 .{ }^{10}$ On the other hand, in the developed country half of neonatal mortality were caused by sepsis. ${ }^{11}$ In this study, the neonatal sepsis mortality rate was still high (40\%). It was caused by the limitations in handling neonatal sepsis in neonatology unit, Moewardi Hospital. Establishing early diagnosis seems to be the main problem. In the diagnosis approach, the neonatology unit, Moewardi Hospital uses risk factors which were categorized into two groups, i.e.

Table 2. Factors affecting the mortality of neonatal sepsis

\begin{tabular}{lccc}
\hline \multicolumn{1}{c}{ Factor } & Odd Ratio $\mathrm{P}$ & \multicolumn{1}{c}{$95 \% \mathrm{Cl}$} \\
\hline Sex (male) & 0.51 & 0.11 & $0.22 ; 1.16$ \\
Birth weight $\leq 2500$ gram & 6.14 & 0.00 & $2.50 ; 15.07$ \\
Transportion & 1.67 & 0.20 & $0.76 ; 3.83$ \\
Blood culture results (positive growth) & 2.04 & 0.91 & $0.89 ; 4.65$ \\
\hline
\end{tabular}

Table 3. Multivariate analysis of factors influencing the mortality of neonatal sepsis

\begin{tabular}{lccc}
\hline \multicolumn{1}{c}{ Factor } & Odd Ratio $\mathrm{P}$ & $95 \% \mathrm{Cl}$ \\
\hline Sex (male) & 0.62 & 0.30 & $0.29 ; 1.54$ \\
Birth weight $\leq 2500$ gram & 5.21 & 0.00 & $2.04 ; 13.32$ \\
Transportion & 1.44 & 0.44 & $0.57 ; 3.61$ \\
Blood culture results (positive growth) & 1.36 & 0.52 & $0.53 ; 3.47$ \\
\hline
\end{tabular}




\section{Acknowledgment}

We would like to thank Endang Dewi Lestari, MD for her contribution in this study.

\section{References}

1. Gerdes JS. Diagnosis and management of bacterial infections in the neonate. Pediatr Clin North Am 2004;51:939.

2. Aminullah A. Masalah terkini sepsis neonatorum. In: Hegar B, Trihono P, Ifran EB, editors. Update in neonatal infection. Naskah lengkap pendidikan berkelanjutan Ilmu Kesehatan Anak FKUI XLVIII. Jakarta: Departemen Ilmu Kesehatan Anak FKUI; 2005. p. 1-15.

3. Klein JO. Bacterial sepsis and meningitis. In: Remington JS, Klein JO, editors. Infection diseases of the fetus and newborn infant. Philadelphia: PA. WB Saunders; 2001. p. 944.

4. Jarvis WR. Epidemiology of nosocomial infection in pediatric patients. Pediatr Infect Dis J 1987;6:344-51.

5. Stoll BJ, Hansen N, Fanaroff AA, Wright LL, Carlo WA, Ehrenkranz EA, et al. Late-onset sepsis in very low birth weight neonates: The experience of the NICHD neonatal research network. Pediatrics 2002;110:285-91.

6. Tseng YC, Chiu YC, Wang JH, Lin HC, Lin HC, Su BH, et al. Nosocomial bloodstream infection in a neonatal intensive care unit of a medical center: A three-year review. J Microbiol Immunol Infect 2002;35:168-72.

7. Hafidh Y, Martuti S, Sunyataningkamto. Pola kuman, sensitivitas antibiotika, dan risiko kematian bayi sepsis di RS Dr. Moewardi Surakarta. Sari Pediatr. In press; 2006.

8. Eicher DJ, Annibale DJ. Neonatal sepsis: Evaluation and management. J S C Med Assoc 2002;98:102-7.
9. Bellig LL, Ohning BL. Neonatal sepsis. Available from: url: http//www.emedicine.com/ped/topic2630.htm.

10. Bizzarro MJ, Raskin C, Baltimore RS, Gallagher PG. Seventy-five years of neonatal sepsis at Yale; 1928-2003. Pediatrics 2005;116:595-602.

11. Bang AT, Paul VK, Reddy HM, Baitule SB. Why do neonates die in rural Gadchiroli, India? (Part I): Primary causes of death assigned by neonatologist based on prospectively observed records. J Perinatol 2005;25:S29-34.

12. Sepsis neonatal. Standard pelayanan medik divisi Perinatologi FKUI/RSCM 2004.

13. Aminullah A. Diagnosis dan tatalaksana sepsis pada bayi baru lahir. In: Wahono SS, Lany L, Herminto W, Irawaty A, editors. Hot topics in paediatrics: Pediatri gawat darurat, kardiologi anak, dan perinatologi. Naskah lengkap simposium nasional Ikatan Dokter Anak Indonesia. Balikpapan: Badan Penerbit Ikatan Dokter Anak Indonesia; 2006. p. 221-35.

14. Paul VK, Ramani AV. Newborn care at peripheral health facilities. Indian J Pediatr 2000;67:378-82.

15. Bang AT, Bang RA, Baitule SB, Deshmukh MD, Reddy MH. Burden of morbidities and unmet need for health care in rural neonates: A prospective observational study in Gadchiroli, India. Indian Pediatr 2001;38:952-65.

16. Bang AT, Bang RA, Reddy MH, Deshmukh MD. Methods and the baseline situation in the field trial of home-based neonatal care in Gadchiroli, India. J Perinatol 2005;25:S11-7.

17. Bang AT, Reddy MH, Baitule SB, Deshmukh MD, Bang RA. The incidence of morbidities in a cohort of neonates in rural Gadchiroli, India. J Perinatol 2005;25: S18-28.

18. Brown DR, Kulter D, Rai B. Perinatal/neonatal clinical presentation: Bacterial concentration and blood volume required for a positive blood culture. J Perinatol 1995;15: 157 159. 